\title{
Morphological Description and Ecotypic Variability for Germplasm in Sea Buckthorn (Hippophae salicifoliaD.Don.) Growing Under Higher Himalayan Region
}

\author{
Manisha Negi and Rajani* \\ G.B. Pant University, Pantnagar, 263145, Uttarakhand, India \\ *Corresponding author
}

\section{A B S T R A C T}

\section{Keywords}

Chamoli,

Hippophae

salicifolia, Sea

buckthorn,

Variation

Article Info

Accepted:

06 June 2018

Available Online:

10 July 2018
In the present study, morphological traits of growth, fruits and quality were observed in different genotypes of Sea buckthorn growing naturally in Chamoli district of Uttarakhand, India. The mean performance of plant resources was studied and phenotypic characters were evaluated. Mean values for almost all the characters were found higher in genotype CH-41. Different genotypes showed varied morphology from shrub to tree with plant height ranging from $3 \mathrm{~m}$ to $6 \mathrm{~m}$. The canopy width ranged from $2 \mathrm{~m}$ to $5 \mathrm{~m}$. The fruit colour light yellow and yellow were prominent while orange was also observed in few genotypes. Fruits ripened between September and November with profuse to sparse fruit bearing. Among the growth parameters, leaf length ranged from 4mto $8 \mathrm{~m}$ indicating high variability. Ten genotypes also differed in fruit weight from 2.60 to $4.38 \mathrm{~g}$ and similar trend was also observed in fruit length. Biochemical characters were largely dependent on growth characters and also showed remarkable variation in juice percentage and TSS level.

\section{Introduction}

Hippophae (commonly known as Sea buckthorn) is an actinorhizal plant having symbiotic association with Frankia. The genus Hippophae comprises of seven species. All species are diploid, wind pollinated, and dioecious, and are restricted to the Qinghai Plateau and adjacent areas, with the exception of the species Hippophae rhamnoides L. that occurs widely but sporadically in Asia and Europe (8). The female plant bears red, orange or yellow berries on two-year-old thorny twigs. Sea buckthorn berries are among the most nutritious of all fruits and have immense medicinal properties. Concentrations of vitamins $\mathrm{B}_{2}, \mathrm{~B}_{3}, \mathrm{~B}_{5}, \mathrm{~B}_{6}, \mathrm{~B}_{12}, \mathrm{C}$ and $\mathrm{E}$ are much higher than other fruits such as apricot, banana, mango, orange and peach (7). Sea buckthorn extracts possess antibacterial activities and have shown protective effect against the toxic effect of mustard gas, a chemical warfare agent (10).

Fresh Sea buckthorn berries are rich in nutrients such as carbohydrates, organic acids, amino acids, vitamin $\mathrm{C}$, carotenoids, minerals, vitamin $\mathrm{B}$, vitamin $\mathrm{E}$ and vitamin $\mathrm{K}$. The 
vitamin content of Sea buckthorn is much higher than any other fruit or vegetable. Because of its high content of vitamin C, Sea buckthorn is usually used to make soft drinks and other similar food products. Seeds contain high quality oil which has many bioactive substances (5). The plant is able to tolerate abiotic stresses like high salt concentration, water, soil nutrient and low temperature stresses etc. under the moist and hostile climatic conditions of dry Himalayas. Other plant parts viz. leaf, stems, seed, bark are also rich in medicinal properties which have been used in traditional system of medication for treatment of various ailments. It is estimated that the age of Sea buckthorn is more than 320 years and it is still bearing fruit. Several studies on physiochemical compounds of sea buckthorn berries have been published in India (4) and China (9). No detailed comparative reports have been published on physiochemical composition of different sea buckthorn genotypes naturally grown in Uttarakhand especially of sea buckthorn growing area in Chamoli region which has a unique geoclimatic conditions of high altitude coupled with extreme variations in temperature.

Thus, present investigation was carried out for evaluation of different genotypes of sea buckthorn from different locations of Chamoli (CH) district in Uttarakhand.

\section{Materials and Methods}

The investigation was carried out by using 10 genotype of Sea buckthorn species salicifolia from different locations of Chamoli $(\mathrm{CH})$ in Uttarakhand. The genotypes were investigated for morphological and genetic diversity. The mature fruits of Hippophae salicifolia were collected from 10 different locations in Chamoli and plant characters were observed. Information about the sampling sites and their locations are given in Table 1.
Morphological characters investigated were plant height $(\mathrm{m})$, plant form, thorniness, immature stem color, canopy width (m), inter branch distance $(\mathrm{cm})$, upper leaf surface (Adaxial side), adaxial leaf surface color, color of the midrib on the adaxial side, leaf tip shape, leaf length $(\mathrm{cm})$, leaf width $(\mathrm{cm})$, leaf pedicel length $(\mathrm{mm})$, fruit color, fruit ripening month, density of fruit bearing, fruit length $(\mathrm{mm})$, fruit width $(\mathrm{mm})$, fruit weight $(\mathrm{g})$, fruit peduncle length $(\mathrm{mm})$, juice percentage, fruit acidity and fruit total soluble solids (TSS). The average values were calculated for each character using different replications.

The fruit characters were observed and seeds were extracted from the berries by squeezing them in muslin cloth. Morphological as well as the genetical investigations were carried out to determine the variability that exists among the different genotypes of Sea buckthorn. The result were subjected to 'analysis of variance and correlation coefficient' and tested for significant differences at $5 \%$ level of significance.

\section{Results and Discussion}

Morphological as well as the genetical investigations were carried out to determine the variability that exists among the different genotypes of Sea buckthorn. The result were subjected to 'analysis of variance and correlation coefficient' and tested for significant differences at $5 \%$ level of significance. Morphological characters observed in Sea buckthorn plant and fruit are presented in Table 2. Similar results are found regarding to fruit color of yellow and yelloworange colour with round, spherical, roundoval and round-cylindrical shapes(11).

General mean for the different morphological traits of plant are presented in Table 3 . According to the result for leaf characters, leaf length ranges between $4.00 \mathrm{~cm}-8.00 \mathrm{~cm}$ and mean value is $5.94 \mathrm{~cm}$. 
Table.1 Characters of sampling sites

\begin{tabular}{|l|l|l|l|l|l|}
\hline S.No. & Sample No. & Location & Altitude (m) & Longitude & Latitude \\
\hline 1. & $\mathbf{C H}-\mathbf{1 2}$ & Jhelam village & 2781 & $30^{\circ} 38.380$ & $079^{\circ} 49.700$ \\
\hline 2. & $\mathbf{C H}-\mathbf{1 3}$ & Jhelam village & 2778 & $30^{\circ}{ }^{\circ} .312$ & $079^{\circ} 49.725$ \\
\hline 3. & $\mathbf{C H}-\mathbf{1 7}$ & Long tamak river & 2442 & $30^{\circ} 35.701$ & $079^{\circ} 49.700$ \\
\hline 4. & $\mathbf{C H}-\mathbf{4 1}$ & Hanuman chatti & 2699 & $30^{\circ} 40.600$ & $079^{\circ} 30.695$ \\
\hline 5. & $\mathbf{C H}-\mathbf{4 3}$ & Hanuman chatty & 2761 & $30^{\circ} 41.579$ & $079^{\circ} 30.691$ \\
\hline 6. & $\mathbf{C H}-\mathbf{9}$ & Jhelamtamak & 2784 & $30^{\circ} 78.718$ & $079^{\circ} 49.812$ \\
\hline 7. & $\mathbf{C H}-\mathbf{1 0}$ & Ghaturi village & 2770 & $30^{\circ}{ }^{\circ} .508$ & $079^{\circ} 49.753$ \\
\hline 8. & $\mathbf{C H}-\mathbf{1 6}$ & Long tamak river & 2452 & $30^{\circ} 35.720$ & $079^{\circ} 47.102$ \\
\hline 9. & $\mathbf{C H}-\mathbf{1 4}$ & Jhelam forest nursery & 2775 & $30^{\circ} 38.103$ & $079^{\circ} 49.661$ \\
\hline 10. & $\mathbf{C H}-\mathbf{1 5}$ & Jhelam village & 2810 & $30^{\circ} 38.135$ & $079^{\circ} 49.685$ \\
\hline
\end{tabular}

Table.2 Morphological characters observed in Sea buckthorn plants

\begin{tabular}{|c|c|c|c|c|c|c|c|c|c|c|}
\hline Characters & $\mathrm{CH}-12$ & $\mathrm{CH}-13$ & CH-17 & $\mathrm{CH}-41$ & $\mathrm{CH}-43$ & CH-9 & $\mathrm{CH}-10$ & CH-16 & $\mathrm{CH}-14$ & CH-15 \\
\hline Plant height (m) & $3-4$ & $2-3$ & $4-5$ & 5 & 5.5 & $4-5$ & $6-7$ & $4-5$ & $6-7$ & $5-6$ \\
\hline Plant form & Shrub & Shrub & Shrub & Shrub & Shrub & $\begin{array}{l}\text { Small } \\
\text { tree }\end{array}$ & $\begin{array}{l}\text { Small } \\
\text { tree }\end{array}$ & $\begin{array}{l}\text { Small } \\
\text { tree }\end{array}$ & Tree & Tree \\
\hline Thorniness & Present & Present & Absent & Present & Present & Absent & Absent & Absent & Present & Present \\
\hline Immature Stem color & Ashy & Silvery & Ashy & Brown & Brown & Silvery & Ashy & Ashy & Silvery & Silvery \\
\hline Canopy width (m) & $2-3$ & $2-3$ & $3-4$ & 4 & $4-5$ & $2-3$ & $4-5$ & $2-3$ & $3-4$ & $3-4$ \\
\hline $\begin{array}{l}\text { Inter branch distance } \\
(\mathrm{cm})\end{array}$ & $30-40$ & $40-50$ & $35-40$ & $35-50$ & $35-40$ & $45-50$ & $35-45$ & $40-45$ & $45-50$ & $40-50$ \\
\hline Adaxial side & Smooth & I.M & Smooth & Smooth & I.M & I.M & I.M & Smooth & I.M & I.M \\
\hline $\begin{array}{l}\text { Adaxial leaf surface } \\
\text { color }\end{array}$ & $\begin{array}{l}\text { Dark } \\
\text { green }\end{array}$ & $\begin{array}{l}\text { Dark } \\
\text { Green }\end{array}$ & $\begin{array}{l}\text { Dark } \\
\text { green }\end{array}$ & $\begin{array}{l}\text { Dark } \\
\text { green }\end{array}$ & $\begin{array}{l}\text { Dark } \\
\text { green }\end{array}$ & $\begin{array}{l}\text { Dark } \\
\text { green }\end{array}$ & $\begin{array}{l}\text { Dark } \\
\text { green }\end{array}$ & Green & Green & Green \\
\hline $\begin{array}{l}\text { Color of leaf midrib or } \\
\text { the abaxial side }\end{array}$ & G.B & G.B & G.B & Green & Green & G.B & Green & G.B & Green & G.B \\
\hline Leaf tip shape & Acute & Acute & I.M & Acute & I.M & I.M & Acute & Acute & Acute & I.M \\
\hline Fruit color & Yellow & L.Y & Orange & L.Y & Yellow & Yellow & Yellow & L.Y & Yellow & L.Y \\
\hline Fruit ripening month & $\begin{array}{l}\text { Oct } \\
\text { Nov }\end{array}$ & $-\mathrm{Nov}$ & Sep - Oc & $\begin{array}{l}\text { tOct } \\
\text { Nov }\end{array}$ & $\begin{array}{l}- \text { Oct } \\
\text { Nov }\end{array}$ & $\begin{array}{l}- \text { Oct } \\
\text { Nov }\end{array}$ & $\begin{array}{l}- \text { Oct } \\
\text { Nov }\end{array}$ & - Nov & Oct -Nor & vNov \\
\hline Density of fruit bearing & & $\mathrm{P}$ & $S$ & I.M & $\mathrm{P}$ & $\mathrm{S}$ & $\mathrm{S}$ & I.M & $\mathrm{P}$ & $\mathrm{P}$ \\
\hline
\end{tabular}


Table.3 Mean value of different morphological traits for plant characters of Seabuckthorn

\begin{tabular}{|l|l|l|l|l|l|}
\hline S.No. & Character & Range & Mean & S.Em \pm & C.V \\
\hline 1. & Leaf length $\mathbf{( c m )}$ & $4.00-8.00$ & 5.94 & 0.427 & 22.769 \\
\hline 2. & Leaf width $(\mathbf{c m})$ & $0.30-1.50$ & 0.82 & 0.132 & 51.032 \\
\hline 3. & Leaf peduncle length $\mathbf{( m m )}$ & $0.20-0.70$ & 0.33 & 0.049 & 47.485 \\
\hline 4. & Fruit length $(\mathbf{m m})$ & $4.02-6.91$ & 5.90 & 0.306 & 16.400 \\
\hline 5. & Fruit width $(\mathbf{m m})$ & $3.91-6.62$ & 5.45 & 0.278 & 16.152 \\
\hline 6. & Fruit weight $\mathbf{( g m )}$ & $2.60-4.38$ & 3.28 & 0.175 & 16.939 \\
\hline 7. & Fruit peduncle length $\mathbf{( m m})$ & $0.94-3.10$ & 1.69 & 0.213 & 39.758 \\
\hline 8. & Juice percentage & $54.34-91.00$ & 68.16 & 3.527 & 16.365 \\
\hline 9. & Fruit acidity & $3.16-4.01$ & 3.51 & 0.078 & 07.064 \\
\hline 10. & Fruit total soluble salt & $9.00-14.00$ & 11.45 & 0.761 & 21.038 \\
\hline
\end{tabular}

Leaf width ranges between $0.30 \mathrm{~cm}-1.50 \mathrm{~cm}$ and mean value is $0.82 \mathrm{~cm}$. Leaf peduncle length ranges between $0.20 \mathrm{~mm}-0.70 \mathrm{~mm}$ and mean value is $0.33 \mathrm{~mm}$. According to fruit results, fruit length ranges between 4.02 $\mathrm{mm}-6.91 \mathrm{~mm}$ and mean value is $5.903 \mathrm{~mm}$. Fruit width ranges between $3.91 \mathrm{~mm}-6.62$ $\mathrm{mm}$ and mean value is $5.458 \mathrm{~mm}$. Fruit weight ranges between $2.60 \mathrm{~g}-4.38 \mathrm{~g}$ and mean value is 3.285 . Fruit peduncle length ranges between $0.94 \mathrm{~mm}-3.10 \mathrm{~mm}$ and mean value ranges between $1.698 \mathrm{~mm}$. The average fruit length varied from 5.0 to 11.0 $\mathrm{mm}$ and fruit width ranged from $4.2-7.8$ $\mathrm{mm}(3)$. It have been reported earlier that, berry size varies from $5.38-5.42 \mathrm{~mm}$ (2). Similar results have been reported by (11) that the fruit length and breadth varied from 5.78 to $7.92 \mathrm{~mm}$ and 5.51 to $7.24 \mathrm{~mm}$ respectively. It have been reported earlier that, fruit size ranges between 6.17 to $9.87 \mathrm{~mm}$ in length, 4.16 to $7.86 \mathrm{~mm}$ in width(1). The juice percentage, fruit acidity and fruit total soluble solid vary from 54.34 to $91.00,3.16$ to 4.01 and 9.00 to 14.00 . It have been reported that juice percentage, fruit acidity and total soluble salt of Sea buckthorn berries varied from 72.9 to $85.0,1.46$ to 3.62 and 8.7 to 13.8 (6).

The pattern of variability in morphological characteristics associated with habitat, plant growth habit, stem, leaf, fruit, flower, seed and biochemical parameters were taken into consideration. Mean values for almost all the characters are found higher in the genotype $\mathrm{CH}-41$. Seed length is found maximum and highly significantly positive at genotypic and phenotypic level with seed form and 100 seed weight, and 100 seed weight show positive and significant correlation with seed width at both genotypic and phenotypic level. Negative and highly significant correlation at genotypic and phenotypic level is found in seed thickness with form of seed cross section. Therefore, it can be noted that genotypes taken for study had wide range of variation for morphological characters, so there is more scope for improvement of these characteristics. 


\section{References}

1. Aras A, Akkemik U, Kaya Z (2007) Hippophae rhamnoides L.; Fruit and seed morphology and its taxonomic problems in Turkey. Pak J Bot 39(6): 19070-1916

2. Chauhan AS, Rekha, MN, Ramteke RS, Eipeson WE (2003) Seabuckthorn (Hippophae rhamnoides Lin.) berries harvesting its potential for processing. J Food Sci. Tech 40 (4): 349-356

3. Dwivedi SK, Singh R, Raut B (2003) Studies on distribution pattern of seabuckthorn through remote sensing and its genetic diversity in Ladakh. In: International Seabuckthorn Association Congress, Berlin, Spet 1418, 2003, Abstract, p.29

4. Ranjith A, Kumar KS, Venogupalan VV, Arumughan V, Shawney RS, Singh V (2006) Fatty acids, tocols, and carotenoids in pulp oil of three Sea buckthorn species (Hippophae rhamnoides, $H$. salicifolia, and $H$. tibetana) grown in the Indian Himalayas. J Amer Oil Chemists Soc83: $359-364$

5. Rongsen L (1992) Seabuckthorn: A multipurpose Plant Species for fragile mountains. Occasional paper No. 20, ICIMOD, Kathmandu 62p

6. Singh V, Singh B, Awasthi CP (1995) Distribution, taxonomy and nutritional values of Sea buckthorn growing in dry temperate Himalayas. In: Proceeding of International workshop on Sea buckthorn, Beijing, China, Dec. 12-17, 1995. Beijing, China, pp.
52-59

7. Stobdan T, Chaurasia OP, Korekar G, Mundra S, Ali Z, Yadav A (2010) Attributes of sea buckthorn (Hippophae rhamnoides L.) to meet nutritional requirements in high altitude. Defence Sci J60: 226-230

8. Stobdan T, Korekar G, Srivastava RB (2013). Nutritional attributes and health application of Seabuckthorn (Hippophae rhamnoides L.) - a review. Cur Nutrition Food Sci 9: 151165

9. Tong J, Zhang C, Zhao Z, Yang Y, and Tian K (1989) The determination of physical chemical constants and sixteen mineral elements in sea buckthorn raw juice. In: Y. Ma (Ed.), Proceedings of international symposium on sea buckthorn $(H$. rhamnoidesL.). Xian, China: International Seabuckthorn Association. pp. 132-137

10. Vijayarahgavan R, Gautam A, Kumar O, Pant SC, Sharma M, Kumar HTS (2006) Protective effect of ethanolic and water extracts of sea buckthorn (Hippophae rhamnoides L.) against the toxic effects of mustard gas. Indian J ExperBiol 44: 821-831

11. Yadav VK, Sharma SK, Sah VK Singh V (2006) Morphological and biochemical diversity in sea buckthorn (Hippophae salicifolia D.Don.) populations growing in Harsil area of Garhwal Himalaya, India. Tropical Ag Res Ext., 36(4): 3-25

\section{How to cite this article:}

Manisha Negi and Rajani. 2018. Morphological Description and Ecotypic Variability for Germplasm in Sea Buckthorn (Hippophae salicifolia D.Don.) Growing Under Higher Himalayan Region. Int.J.Curr.Microbiol.App.Sci. 7(07): 479-483.

doi: https://doi.org/10.20546/ijcmas.2018.707.058 